\title{
The State Authority Constitutional Legitimacy in Modern Russia
}

\author{
Pavel P. Baranov ${ }^{1}$ \\ Aleksey I. Ovchinnikov² \\ Aleksey Y. Mamychev ${ }^{3}$
}

${ }^{1}$ South-Russian Institute of Management of the Russian Academy of National Economy and State Service under the RF President ${ }^{2}$ Rostov State Institute of the MIA of Russia

3Vladivostok State University of Economics and Service; Email: mamychev@yandex.ru

Doi:10.5901/mjss.2015.v6n5s3p201

\section{Abstract}

This paper analyzes the theoretical and methodological problems of constitutional legitimacy, gives its definition, and offers a characteristic of element of the constitutional legitimacy, made out the case of its identity to rational legitimacy. It is grounded that the formal-normative (legalization) and the socio-political aspect (legitimization) in the functioning of state authorities comprehensively characterize the existing institutional and power organization, reflect the level of constitutional and political consolidation in society, sustainability and stability of public law relations. The authors draw attention to the problems in the constitutional legitimization of power in modern Russia in the context of its socio-cultural, legal and political identity, exploring the potential constitutional and legal power resources and formulate a number of offers for improving the mechanism of constitutional-legal regulation in the Russian Federation. In the article it is argued that constitutional legitimacy is based on historical tradition and political and legal continuity and social support of the declared principles and fundamental (constitutional) relationships. This shows that the "crisis of legitimacy" acts as the main reason for large-scale and revolutionary state changes.

Keywords: legitimacy, constitutional legal sense, state authority; state, constitutional legitimacy, constitutional system.

\section{Introduction}

Problematization in research projects of the concepts of "legitimacy" and "legality" is caused by the crisis of state authority, which is conceived now as the result of transition from one "paradigm of ruling", the traditional and organically evolving along with society, to another, fundamentally different, on configuration, maintenance, operation of the key political and legal institutions and on strategies, tactics, types and ways of development of relations of power. In other words, this crisis is associated usually with processes of political and legal modernization of society. The latter in modern literature is perceived as an essential attribute of modernization processes.

Therefore, the concept of "legitimacy" has its shades of meaning and heuristic possibilities, due to spatial-temporal and socio-cultural factors. Namely the historical-cultural background largely determines the meaning, content and practical effectiveness of this concept at a certain period of time. In this sense, "to offer" to formulate a universal theory of legitimacy, practically and theoretically valid, invariant for all times and cultures-civilizational spaces, as seen, is not possible.

Today it is clear that the appeal to the historical and cultural conditions of the conceptualization of the concepts of "legitimacy" and "legality", their evolution within the framework of this or that state law reality allows to identify; first, specific types, models of legitimization and legalization of the power inherent in one or another socio-cultural universe, secondly, the features of functioning and the maintenance of specific institutional orders and their continuity, and, thirdly, to compare state and legal experience with their theoretical and practical ways of legitimation, developed in the framework of one or another civilization.

\section{Literature Review}

For a long time the concept of "legitimacy" was used in the scientific revolution, usually in the context of the legal system knowledge (Lubashic V. J., Mordovtcev A. Y., Mamichev A. Y., 2013). Its semantic crystallization proceeded in close 
apposition with such terms as "legality" and "legitimacy", "the implementation of law", "law enforcement", etc. For example, in many studies "legitimacy" is explained as real perception, political and legal bases, the justification of practical activities of any persons, authorities, their legal adequacy of the existing institutional and normative order, to the requirements of natural law and so on. (Dibirov A.N-3., 2007)

However, as noted by many researchers, this understanding of "legitimacy" is peculiar to a rational-legal discourse, which was emerged and was embodied in the classical legal paradigm. (Bachinin V.A., Salnikov V.P., 2000). Moreover, the semantic content of the concept "legitimacy" and its theoretical and methodological functions were developed in the context of Western European civilization (Dyuverje M., 1997). Therefore, in many cases Western theoretical calculations on the "theory of legitimation" at transfer to a different socio-cultural plane does not "catch" the specificity of various cultural universes, which greatly impoverishes research results (Alexey I. Ovchinnikov, Alexey Y. Mamychev, Svetlana F. Litvinova, 2015). For example, there is a huge gap between Western theory of legitimacy based on formal-rational, targeted and electoral presumptions, and domestic, based on the traditionally-ideocratical principles: the belief in the "idea-ruler", the sanctity of national traditions, spiritual and moral dimension of the nature of state power (Baranov P.P., Gorshkolepov A.A., 2002).

Today, the term "legitimacy" is widespread not only in the framework of political and social science, but also in law, acquiring the value of one of the fundamental, essential characteristics of state power (Andrey Y. Mordovcev, Tatyana V. Mordovceva, Aleksey Y. Mamichev, 2015). In legal science was traditionally used the term "legality", despite the fact that initially the legitimacy was understood as the legitimacy of power. As you know, the emergence of the term "legitimacy" is associated with the nineteenth century in France, when this term was used to characterize the government as a "legitimate authority" as opposed to the power of Napoleon, which was recognized as illegal and encroached (Chirkin V. E., 1995).

Gradually in understanding of the legitimacy of power began to dominate not legal but socio-psychological element - the approval, recognition, and respect to power structures. The distinction of the terms "legitimacy" - Fr. legitimite and "legality" - фp. Legalite is based on that (Bukovansky M., 2002). In modern legal literature under the influence of sociological jurisprudence, the term "legitimacy" is already used as a broader-scale concept than "legality". But as the subject of analysis is right, then, it is accepted to talk about the legitimacy of law, legal policy, certain legal institutions (Alexey Y. Mamychev, Evgeniya Y. Kiyashko, Alla A. Timofeeva, 2015). In this article an attention will be focused on constitutional and legal legitimacy or constitutional legitimacy, which is understood as the conformity with the Constitution and with the constitutional values enshrined in the constitutional conscience of society, the forms and methods of exercise of public authority, the lawfulness of the policy of the state. It should be, by many researchers, differentiated the legality of power, which is traditionally understood as the right to rule in accordance with the law, i.e. the legal right to control public processes, regulation and control over public relations (Giddens A., 1988). The legality of state authority is a juristic category regulated by the legislation of the activities of public authorities and its legal establishment.

It is well known that Western jurisprudence and political science in virtue of the rationality of political and legal thinking is characterized by the convergence of the terms "legality" and "legitimacy", as well as the rational legitimacy and constitutional legitimacy (Rogowski R., 1974). In everyday consciousness the concept of "legitimacy" is also often equated with "legality". For example, the media and politicians in February 2014 during the events on Maidan called V. Yanukovych legitimate President. However he was legitimate only for a narrow layer close persons, and the majority of the public treated him negatively. So he, is rather, legal, legally elected President.

In this regard, relying on existing literature, to analyze the legal and political system of Russia more adequately is the traditional distinction between the concepts of "legality" and "legitimacy" of the government and law (Kobersy, at al., 2015). The fact is that unlike the formal-rational, value-rational style of political and legal thinking in the first place in the evaluation scale in relation to power and its legal policy puts not correspondence to the procedure, but the value of the equity or value of one kind or another - ethical, political, and other pragmatic and etc. Therefore, the authorities may not be quite legal, but legitimate (Lira J., 1988; Beetam D.; 1991 \& Bourdieu, 1993).

\section{Methods and Materials}

The present study used the methods of comparative legal, when comparing tendencies and development trends of political and legal processes in Russia and other state and legal spaces; historical and legal, allowing to describe the transformation of state power in the course of development of the national constitutional process; ethno-political and specific sociological, allowing to trace the continuity in the political and legal development, in the power-legal thinking activity of political subjects, depending on time, territory, and ethnic groups. To analyze trends and prospects of development of the constitutional legitimacy of state authority were used methods of legal-political simulation of the 
existing political and ideological discourses and their influence on the development of Russian state power.

In this article the analysis of the constitutional legitimacy of power is based on the following methodological circumstances.

First, due to the fact that the Constitution is the fundamental law of the state, the legitimacy of the elite is due to the attitude of the population to the Institute of state and to the Constitution itself. The attitude to the institution of the state is determined by the historical concepts about the nature and origin of the state, law and state authority in Russia. Therefore of utmost importance for the legitimacy of authority is a question of a unified history textbook. Attitude to the Constitution of 1993 is still neutral, but at any time the risk of the audit remains: the complexity and contradictions of its adoption after the events of August 1993 is well known.

Secondly, the constitutional legitimacy of state authority can be determined by the ratio of population to the models of mechanisms of formation of this authority, spelled out in the Constitution and based on it laws.

Thirdly, the legitimacy of state authority can be determined by the way of keeping to its legal procedures in the process of its formation stated in the Constitution. The level of compliance with the formal conditions of formation of the institutions of authority concerns the formation of the authorities on the basis of modern "democratic" procedures and other methods of forming power.

Fourthly, in public legal awareness level of constitutional legitimacy, for example, the Federal and local authorities may not be the same. The idea is that, in general, supporting the policies of the state and accepting and agreeing to the principles of forming the government at the Federal level and the implementation of the whole set of procedures laid down in the law, people may not take similar authorities at the local level, taking into account all the above reasons and its weak efficiency. It is not a secret that in the public consciousness municipal authorities are perceived as a "continuation" of state bodies.

\section{Results and Discussions}

Value-rational legitimacy is characteristic of the Russian political tradition, where ideocratic, ideological, value-idealistic guidelines still play a big role. Much more important component of legitimacy in Russia is the presence of the expected values in the content of the laws, which in juristic is called "desired right". Therefore, the constitutional legitimacy of authority in Russia presupposes the existence of the desired law in legal policy and the use of law by authorities. The constant lack of legal support of desired values in the policies of the authorities leads to the search for the legitimacy of alternative elite (Sherlock T., Beitler R.M., 2006, p. 23).

Socio-cultural specifics of the Russian political system are that the authority, the time of occurrence of which is based on clear and transparent legal procedures, can't always get its recognition in the public consciousness. On the other hand, the authority, though being a result of "illegal" and "undemocratic" procedures may ultimately receive approval in the public consciousness directly as a result of its positive influence on the lives of people. Therefore, the constitutional legitimacy of authority is not always equal to its legality and rational legitimacy. This situation is typical for countries with a traditional political culture. The constitutional legitimacy is not identical to the rational legitimacy: The basic law of the country does not necessarily have to secure the rights and freedoms of human rights, pluralistic democracy, parliamentarism and other elements of legitimacy of modern democracies.

Rational legitimacy is based on democratic and open organization and "transparent" procedures of state authorities. As a rule, rational legitimacy derives from such organization of the state in which are strictly respected and protected human rights, observed general democratic principles of management and properly is protected law and order in general. The constitutional legitimacy of power is very close to rational. But if the Constitution, for example, puts the value of national interests or state safety above the interests of the individual, and the government strictly adheres to this rule, then we can talk about the constitutional legitimacy that does not coincide with rational, because rationality and individualism are closely linked.

Thus, the political regime as a whole can remain constitutional and legitimate also at openly expressed distrust of individual institutions or heads of state. If the identity of the President is unpopular, it does not necessarily imply a distrust of the institution of the presidency in general.

Fifth, the constitutional legitimacy in a particular state depends on the type of legitimation in general, as it is its component.

It should be noted that modern society in most states differ namely in the rational legitimacy of power. In the end, it is possible to distinguish three main varieties, which are based on the major systems of state structure in modern world. After all, it is impossible not to agree with the statement that "the main focus associated with external recognition of state authority, stems from the nature of the political regime established in the state (Dibirov A.N, 2007, p. 246). 
The days when the Constitution testified to the liberal democratic regime and the constitutional state have gone. In this regard, taking into account socio-cultural features of constitutional justice in different countries, we can distinguish different types of constitutional legitimacy. In those states where the law protects the modern liberal democratic values is present liberal constitutional legitimacy; where the Constitution enshrines these values, but the political regime in fact is different we can speak about formal constitutional legitimacy; countries in which the Basic law enshrines monarchical regimes, conservative, religious values, you can speak about constitutional values of legitimacy.

Let's try to answer the question of which of the above three types of legitimacy can be attributed to the existing constitutional legitimacy of state authority in Russia. The Constitution of Russia from the point of view of liberal values is exemplary. Political life, in general coincides with the Constitution, with the exception of a few features of liberal democratic regimes, for example, the absence of institutional opposition. The norms guarantying social rights of the population remain not implemented. But overall, the majority of citizens of Russia, as opinion polls show, support state authority and therefore the current authority possess constitutional-democratic legitimacy.

But at the same time in modern Russia are manifesting many signs of "formal constitutional legitimacy". In these circumstances, in our opinion, the task of domestic science of constitutional law is to develop concrete proposals for improvement of the constitutional and legal regulation for the purpose of overcoming of the crisis phenomena. In this regard, we can only regret that scientific articles which contain only extremely sharp politicized conclusions about the full simulation of the constitutional system in Russia began to appear and there are no proposals to improve the political system of society (Denisov S.A., 2012, p. 2-8).

Discussing the essential characteristics of constitutional legitimacy of authorities, it should be remembered that many researchers talk about the need for a distinction between understanding the legitimacy of authority and the degree of credibility on the part of the population. On the one hand, this problem appears to be transparent enough. In the case of the discussion of the term "constitutional legitimacy" it is about the constitutional Institute of authority formation, its principles, special procedures and their compliance. If these features both formal and conceptual and ideological nature are observed, the authority is constitutionally legitimate. Assessment of the level of public confidence in the authorities is determined not only by the above criteria, but by the extent of the authority effectiveness to implement the provisions of the Constitution. Thus, we can say that the degree of trust to the authorities is determined also by the level of its constitutional legitimacy, and the term "trust" is more general in relation to the term "legitimacy". However, the situation seems clear at first glance.

Even the authority generated by quite legal and "legitimate" from the point of view of the Constitution method may be, and very often is in a situation where the inefficient functioning of the main institutions of authority again puts on the agenda the question of its constitutional legitimacy; there happens a "deception expectations." Psychologically, it looks like this: people who are not able to implement the constitutional guarantees to the population came to power through "cheating", came to power illegally and have no right to be in the government. This explains the fact that, despite formal observance of all legal procedures, the authority in the constitutional public consciousness is not such. Also, should not be forgotten the situations of the absence of real political competition, or the possibility of real political choice at all. In cases where people involved in a real democratic procedures for the implementation of the elections, have to vote on the principle, "not to be worse," or "important to against, and for whom doesn't matter", legitimacy is under serious question.

Thus, being one of the indicators of relationship to authority in a particular society and state, constitutional legitimacy is also an indicator of the effectiveness of the law enforcement activities of the authorities in the public consciousness, not being an absolute value. Considering the wide range of issues that have to be considered when researching the level of constitutional legitimacy, it can be said that in general it is derived from two key characteristics of government - constitutional procedures for its formation and the degree of effectiveness of the implementation rules of constitutional law. Thus, in the political and legal importance in modern Russia under constitutional and legal legitimacy, in our opinion, should be understood the positive attitude of the population to the current Constitution and its institutions of state authority, the recognition of their being "legitimate" in the public consciousness. This is completely voluntary and objectively predefined recognition by the people of "constitutional right of authority to rule".

With the concept of legitimacy is closely related the problems of constitutional delegitimization of the state authority that are particularly relevant for modern Russia. As noted by many researchers basic premise of delegitimization overall modern Russian authorities have ideological and not formal legal implications. Increasingly, however, it is possible to hear that "the authority does not provide an implementation of socio-economic rights", "social state principle, enshrined in the Constitution is ignored", "the principle of separation of powers is formal", etc. This indicates the increasing importance of the Constitution and constitutional justice in social and political life of Russia.

Increasing bureaucratization and corruption among officials, and the criminalization of society in general also advocate as the circumstances contributing to the growing problem of constitutional delegitimization of modern 
authorities. It turns out that in modern constitutional law is poorly represented the institutions of social control and the anti-corruption mechanism.

Many legal scholars have noted that in our country is still poorly developed civil society institutions and virtually there are none of the so-called control "from below" that is exacerbated by the protracted reform of the political system. At the same time, it must be noted that the present Russian regime, finally, fully realizing the enormous relevance of these issues has taken real steps to ensure that the last elections of the Russian President looked the most open, constitutional and democratic.

In our opinion, in the mechanism of providing the constitutional legitimacy of state authority, should be highlighted items such as the extensive use of legislative initiatives in legislative activity from various social groups, civil society institutions; the use of referendums to identify the desired rights of the population; development of the institutions of popular representation through majority elections; public opinion in the activities of legislative and executive power, but most importantly, constant and unwavering law obedience of the state authority.

In many respects, this issue of "law-obedience of state authority" is associated with the attribute of the modern state authority objectively becomes not the right to govern itself and to command but the duty to skillfully organize and implement management activities in the society. Here should be remembered the founder of the theory of solidarism Leon Dyugi, who noted that constitutional laws are binding upon the state, because their aim is to give the state general administration of successful functioning of the control system in society under strict liability of the state for the improper actions of officials committed in his name (Goldenveyzer A.A., 1952, p. 178-180).

However, the current Russian practice shows that the authorities often show examples of "disrespectful" attitude towards the existing laws. For example, the Government's Decree No. 1025 dated 8 October 2012 changed the rules of its activities, and its employees have the right to prepare regulations to implement Federal laws that were adopted by the State Duma in the second reading, but have not still passed remaining procedures (third reading approval by the Federation Council, signing by the President of the Russian Federation). What would it say? It only shows that the executive authority gives the Parliament the role of simple statistician and body, thoughtlessly stamping and "registering" laws, acceptable to the executive authority.

Another example of "unlawful" conduct of public authorities, which, of course, negatively affects their legitimacy, is the non-fulfillment by these bodies of decisions of the constitutional Court of the Russian Federation. From published on the website of the Ministry of justice of the Russian Federation information follows that by June 2012 from 121 adopted over 20 years of decisions of the constitutional Court of the Russian Federation, the legislator has made only 70 , and 51 decisions has not been implemented. Published July 17, 2012 report of the Secretariat of the constitutional Court states that "the regulations of the Federation Council and State Duma do not include specific procedures to ensure timely consideration of bills aimed at execution of decisions of the constitutional Court" (Pushkarskaya A., 2012).

This situation leads to the transfer of consideration of the relevant legislation. For example, because of moving a bill aimed at protecting the electoral rights of citizens, which was to be considered by the State Duma in the spring session of 2011, has not yet been adopted. Non-execution of decisions of the constitutional Court by the government of the Russian Federation is largely due to the fact that the government of the Russian Federation constantly extends and postpones the date of execution of decisions of the constitutional Court on the "requests" of those ministries and agencies which are entrusted to plan projects of relevant legal acts.

The rules of constitutional law have a very serious impact on the entire system of social relations arising in the sphere of legitimacy of state authority. The existing constitutional-legal regulation of the various sides and aspects of legitimacy in contemporary Russian authorities that form within the population of our country a positive attitude to all existing institutions of government is a multidimensional and systemic impact of constitutional law on:

improvement of the economic foundation of a civil society based on effective commodity production and market economy, the real economic freedom and independence of citizens;

- implementation of provisions of the Russian Federation as a social state which policy is aimed at creating conditions for a worthy life of people and their free development;

- implementation of fixed democratic principles in the functioning of the political system, including the guarantee of ideological, political diversity and pluralism, allowing Russian citizens within the law to participate in the political process personally or through independent political movements and associations;

- improvement of the procedure of formation and functioning of the system of presidential power, legislative, executive and judicial authorities, based on the principle of national sovereignty;

- implementation of the rule of the people through the actual mechanism of direct and representative democracy in the Russian Federation;

- implementation of the principle of separation of authorities and guarantee of the system of checks and 
balances between different branches of government, without arbitrariness of any of them;

- functioning of the mechanism of legal liability of all governmental authorities and officials;

- serious democratic transformation of the political systems that are associated with the increasing role of parties and social movements, the media in public life, the development of political diversity, encourage citizens to participate in political life and public administration;

- fixing the real constitutional and legal mechanisms for the resolution of conflicts arising in the sphere of the relations of state and civil society institutions, the establishment of control of civil society over the activities of state bodies and officials.

Nobody wants political instability of the early 90's, however, the presence of permanent and erected in a rank of traditional and untouchable one political force in the absence of even the formal political competition provides fertile ground for the escalation of political nihilism in one part of the population and a sharp increase in political intransigence, not always ideologically grounded, in the other. It should be said that the present Russian regime is aware of this problem and is taking steps to address it. However, the situation when, on the one hand, is facilitated the registration of political associations and, from the other, is significantly narrowed the scope of the realization of the right to freedom of peaceful Assembly, looks quite contradictory.

In this case, when the political alliances may be refused to be registered and the right of participation in the electoral process remains overly formalized. In this regard, should be recalled the norm of five percent of possible defect in the submitted lists in accordance with the Federal law "On elections of President of the Russian Federation" at external expediency can be used a method of combating real political competition, especially because of the subsequent appeal of this decision during the trial will not always have a real value because of missed time. For comparison it can be said that the Federal law "On basic guarantees of electoral rights and the right to participate in referendum of citizens of the Russian Federation" establishes the figure of ten percent, however, indicating that it may be specified in the relevant laws. In this regard, in our view, it is necessary to maintain expressed idea about setting up a special judicial institution to promptly solve "issues" in the election procedures and elections directly.

Separately it is necessary to regulate the often-discussed situation with party lists, when some of the declared candidates are used as a so-called "locomotives" that ultimately leads to not only deprofessionalization of legislative bodies, but also their criminalization, in the case of transfer of the respective mandates. An attention should be paid on how many of athletes and representatives of various "creative" professions are among the deputies. Furthermore, this situation is usually observed at the Federal level, unlike, for example, the level of subjects of the Russian Federation, which also leads to some reflections.

In addition, it is impossible not to recall the existing contradiction between the democratically enshrined ways of elections and their traditional "administrative and mobilization" content and use of administrative and institutional resource of power to influence the eventual result. In this regard, in our view, should be entered the real criminal responsibility for "administrative interference" in the process of free will of citizens of the Russian Federation at any stage of the electoral process. Also there should be a legislative provision for the termination at the performance of election commissions of the leaders who abused the notorious "administrative resource".

In our opinion, the introduction of various barriers for blocs and alliances of political parties should be limited, should be canceled most of discriminatory filters for associations of a political nature, should be introduced the practice of mandatory and full campaign debates, should be increased the duration of the campaign period, election campaigns up to two months.

Thus, the main changes of the Federal law "On basic guarantees of electoral rights and the right to participate in referendum of citizens of the Russian Federation" could contribute to greater transparency of election procedures, as well as increased involvement of ordinary citizens in the mechanisms of control of the elections. The last election of the President of the Russian Federation, in our opinion, clearly showed that the introduction of technical capability to observe the elections at the polling stations through the "world network", though, acts a certain step towards increasing the transparency of the elections, but is rather a "half-measure" and does not give the necessary effect of a significant increase in the legitimacy of the elected authority.

These circumstances are designed to speed up the reform of the Russian legislation in the context of not only the electoral law and the electoral system, but also the constitutional legitimization of the political system of the society as a whole. The protest moods of the last time persistently show a serious lack of legitimacy of decisions taken by authorities at different levels, which have a negative impact on the legal and political culture of Russian citizens. It is necessary to consider that the creation of real political competition in the country with centuries-old traditions of autocracy and absolute rule (including the seventy years of the Communist regime) is a process designed for a long-term.

Recent events in Ukraine demonstrate that the presence of a real political opposition forces able as equals to 
"compete" with the party in power is not a guarantee of democratization of power. There is, therefore, a need at the level of constitutional-legal, legislative regulation to provide filtering of the opposition in the funding and ideological content.

A return to the mechanisms of formation of the State Duma on the basis of a mixed electoral system, which includes both proportional and majoritarian elements, should be supported. However, the question of the procedure of forming the Federation Council does not lost its relevance. Russian President Vladimir Putin on 4 December 2012 signed the Federal law "On the procedure of forming the Federation Council of the Federal Assembly of the Russian Federation" according to which every candidate for governor shall nominate three candidates for Senate, of which he in case of victory will select its representative to the Federation Council. The second "senator" from the constituent territory of the Federation will be delegated to the Federation Council of the regional Parliament among its members. Currently in the Federal Assembly of the Russian Federation on the initiative of some deputies and senators are considering an offer which empowers the President of the Russian Federation the right to offer for inclusion in the structure of the Federation Council on the posts of senators (up to $10 \%$ of the total number of members of the Supreme chamber of their choice citizens who have extensive experience in senior government positions).

It should be noted that the procedure of formation of Council of Federation has repeatedly changed. Existing law on the procedure for forming the Federation Council has shown its ineffectiveness for the reason that it created only the illusion of electing senators. It appears that the new law should provide a mechanism which will let largely to reflect the actual will of the citizens.

As for the institution of elections of heads of constituent territories of the Russian Federation, taking into account beneficial effects of its return, must not be forgotten the reasons why it was abolished. Also, in this context relevant remains the problem of legislation of responsibility of the elected official to the voters and strengthening the principles of political competition in the electoral process at the local level. It is impossible not to take into account the problem of selection of heads of municipalities..

Analyzing the issue of the referendum in the Russian Federation it should be noted that at the level of constituent territories of the Russian Federation, a referendum is rarely used, much less than rise of any relevant reasons. At the level of local self-government the institute of the referendum is increasingly replaced by "identification of opinion", the result of which is usually a foregone conclusion. As for the Federal level, the institute of the referendum is not used at all. This, of course, not about the institutions of democracy to be used direct every day, but also to bring to this situation, when the public starts to forget about them, is also not possible.

In the context of the development of mechanisms of constitutional legitimization of the existing government the judiciary should also be made more independent from the executive branch, and the procedure of forming members of the judiciary should be made more open, public, and independent for the purpose of democratization. It appears that to this important task will not help introduced in 2012 provision stating that the chairmen of courts of general jurisdiction will now remain at their posts without age restrictions and terms of officiating.

It should be noted that as one of the causes of the crisis of legitimacy of modern authority is weak development of civil society institutions. It is not a secret that the category of "civil society" today is one of the most "mysterious" in modern Russia. The researchers note that when creating a new Basic law, usually two major trends are fighting: to make the Constitution a fundamental law of the state, or the fundamental law of society. In 90-ies in Russia the first trend has won, as a result there were almost no places for civil society in the Constitution, and perhaps for this reason in modern Russia civil society is still in a protracted stage of formation. And it is the civil society and its institutions are one of means of legitimation of state power. In this regard, it is necessary to amend the text of the Constitution of the Russian Federation, as well as to develop and adopt a special Federal constitutional law "On civil society in the Russian Federation".

\section{Conclusion}

5.1. The formal-normative (legalization) and the socio-political aspect (legitimation) in the functioning of public authorities comprehensively characterize the existing institutional and power organization; reflect the level of political consolidation in society, sustainability and stability of political relations. Legitimacy is determined by: a) sustainability of public law institutions; b) the level of continuity in the institutional and power development; $c$ ) the level of political agreement and adequacy of the existing procedure of power relations of existing model of interaction "person - society - state"; d) degree of conformity of methods and results of the implementation of state authority to social expectations; e) the level of "social tension" in the implementation of the political management of social life.

5.2. Today in Russia there is the problem of the legitimacy of the text of the Basic law. Taking into account the fact that state ideology stands as one of the ways of legitimation of state authority even in its rational-democratic 
understanding, the authors find counterintuitive, the fact, that in part 2 of article 13 of the Constitution stipulates that no ideology can be established as the state, especially because it does not correspond to the realities of constitutional regulation and the text of the basic law, which fixes a clear ideological principles of liberalism. This is not surprising, since classical constitutionalism is the ideological heir of liberalism, its legal, juridical arrangements. But in the XXI century ideological clichés of modernism are unlikely appropriate and it should be recognized that the Constitution may protect not only liberal but also conservative, socialist, any other values. However, we do not support the call for the abolition of the principle of ideological pluralism, as it does not interfere with the formulation of higher goals and meanings of state, and with "inclusion" in the current Constitution of certain social-political ideals, values and norms. In addition, for registration of the national idea can be used supplementary political and legal tools: strategy, doctrine, concepts.

5.3. The constitutional legitimacy of authority is defined by the principle of stability of the Constitution: every elite should not change the Constitution in own way. In situations where the "constitutional revolution" radically reject the earlier model or the entire historical tradition as a whole, the lack of political and legal continuity and legitimacy of the proclaimed principles and fundamental relations of property and power, significantly inhibits any constitutional modernization. Moreover, namely the "crisis of legitimacy" acts as the main reason for large-scale and revolutionary state changes.

\section{References}

Baranov, P.P. and Gorshkolepov A.A. (2002) Supreme power as ideaology element of statehood // Philosophy of law. № 1 . pp. 15 - 25. Bachinin, V.A. and Salnikov V.P. (1993) Philosophy of law: a brief dictionary. SPb. pp. 320.

Bourdieu, P. (1993) Sociology of politics. M

Goldenveyzer, A.A. (1952) In defense of the law. Articles and speeches. New York. pp. 72

Denisov, S.A. (2012) Modeling of the constitutional system in Russia // the Constitutional and municipal law. №10. pp. 2-8.

Dibirov, A.N. (2007) Theory of political legitimacy: Course of lectures. M. pp. 272

Dyuverje, M. (1997) Political institutions and constitutional law // The anthology of world political thought. M.

Lubashic, V.J., Mordovev A.Y. and Mamychev A.Y. (2013) State power: paradigm, methodology, typology. M. pp. 476.

Pushkarskaya, A. (2012) Dmitry Medvedev has accused the government of nihilism // Kommersant, November $20,2012$.

Chirkin, V.E. (1995) Legalization and legitimation of state authority // State and law. № 8. pp. 64-72.

Alexey, I. Ovchinnikov, Alexey Y. Mamychev and Svetlana F. Litvinova (2015) Extra-Legal and Shadow Functioning of Public Authorities // Mediterranean Journal of Social Sciences. MCSER Publishing, Rome-Italy. Vol 6. No 3. pp. 387-394.

Andrey, Y. Mordovcev, Tatyana V. Mordovceva and Aleksey Y. Mamychev (2015) The Convergence of Law: The Diversity of Discourses // Mediterranean Journal of Social Sciences. MCSER Publishing, Rome-Italy. Vol 6. No 3. pp. 262-270.

Alexey, Y. Mamychev, Evgeniya Y. Kiyashko and Alla A. Timofeeva (2015) Conservative Political Transformation Projects of the Russian Government: The Main Discourses of Contemporaneity // Mediterranean Journal of Social Sciences. MCSER Publishing, RomeItaly. Vol 6. No 3. S. 2. pp. $389-396$.

Beetam, D. (1991) The Legitimating of Power. N.Y. pp. 326.

Bukovansky, M. (2002) Legitimacy and power politics the American and French Revolutions in international political culture. Princeton, NJ: Princeton University Press. pp. 272.

Giddens, A. (1988) Goffman as Systematic Social Theorist / Ervin Goffman: Exploring the Interaction Order. Boston. pp. 270 - 287.

Kobersy, I., Karyagina, A., Karyagina, O., \& Shkurkin, D. (2015). Law as a Social Regulator of Advertisement and Advertising Activity in the Modern Russian Information Space. Mediterranean Journal Of Social Sciences, 6(3 S4), 9. Retrieved from http://www.mcser. org/journal/index.php/mjss/article/view/6705

Lira, J. (1988) Legitimacy of democracy and the socioeconomic system // Comparing pluralist democraties: Strains on legitimacy. Boulder Westview. 1988. pp. 65.

Rogowski, R. (1974) Rational legitimacy: a theory of political support. Princeton Universiti Press. pp. 326.

Sherlock, T. and Beitler R.M. (2006) The fight for legitimacy: democracy vs. terrorism. Westport, Conn. 236. 


\title{
The Legitimacy of Power and Power relations as a Multi-level Political and Legal Phenomenon: Approaches, Interpretation and Conceptualization
}

\author{
Pavel P. Baranov ${ }^{1}$ \\ Aleksey Y. Mamychev² \\ Aleksey I. Ovchinnikov',3 \\ ${ }^{1}$ South-Russian Institute of Management of the Russian Academy of National Economy and Public Administration under the \\ President of the Russian Federation \\ 2 Vladivostok State University of Economics and Service \\ ${ }^{3}$ Rostov Law Institute of the Russian Ministry of Internal Affairs; Email: mamychev@yandex.ru
}

\author{
Doi:10.5901/mjss.2015.v6n5s3p209
}

\begin{abstract}
The article analyzes the legitimacy as a complex, many-sided and multi-level education, argues that the legitimation of power is carried out at different levels, and the process of legitimation involves both individuals and various groups and organizations. It is noted that the legitimacy is represented as a goal of the functioning of all institutions of public authority and as a result, which is meaningfully concretized with a series of interrelated phenomena (legitimization, legitimate regime and etc.). In its turn, the concept of "legitimacy" is interpreted by the authors as the estimated characteristics, applying to either specific political actors and their actions (personified legitimacy), or to existing institutions and public-authoritative activity (institutional, impersonal). The article also introduces the author's approach to the allocation of interconnected levels of legitimacy: 1) the types of internal (motivational) and external (institutional) legitimacy; 2) the types of legitimate domination defining the dominant strategies of substantiation of existing institutions and the ways of social processes managing; 3) the regimes of the legitimation; 4) the forms of substantiation of a state power as such, and its inherent institutional and legal structure.
\end{abstract}

Keywords: power, authority, power relations, institutions, legality.

\section{Introduction}

Traditionally, power, power relations in society, including ways of legitimation of this power and its activities, are described and analyzed by structural-functional approach. Structural power relations and the mechanism of power legitimization very often coincide and are reduced, as a rule, to three interrelated elements: subject, object and content. This structural model of power relations represents the idealized theoretical structure having a number of weak spots in the description and analysis of the actual public-authoritative interactions unfolding in the society.

For example, the most common definition of power within the subject-object model in social science is the following: it is a relationship of domination and subordination in which the will and the actions of some individuals (powerholding subjects) dominate the will and the actions of others (subordinates). The problem seems to be clear. However, even a perfunctory analysis of the existing practices of authorities call into question the previous statement, the logic of the analysis of power relation itself.

Of course, one can agree with the above-stated structural and functional model of legitimation, however, this structural model of legitimacy phenomenon essence describing is a narrow approach, not taking into account the complex and ambiguous process of authoritative and legal organization development and its legitimation in different historical and cultural contexts. Let's state a few thoughts on the subject.

First, this model works with the already existing, stable configuration of institutions and power structures, interpret the processes of legitimation in the context of a certain historical stage of development and practically is not admissible for the description of the transition and crisis conditions of power-political interaction. It does not capture the processes of legitimation of power in the context of replacement, revolutionary breaking or the transformation of institutional power structures.

Second, the thesis that "only the people is a singular subject of power legitimation" and "Power-holding subject should really be aware of its right to the power (potential legitimacy)" refers more to proper than to existed one. It seems 